\title{
Pencegahan Stunting melalui Pelatihan Pemberian ASI Eksklusif dan Makanan Pendamping ASI (MP ASI)
}

\author{
Khoiriyah Isni ${ }^{1}$, Siti Muthia Dinni ${ }^{2}$ \\ 1,2 Universitas Ahmad Dahlan, Indonesia
}

\begin{abstract}
A B S T R A C T
PREVENTION OF STUNTING THROUGH EXCLUSIVE BREASTFEEDING TRAINING AND ASI COMPLEMENTARY FOOD (MP ASI). Randugunting Hamlet is one of the hamlets that have the highest number of children under five in the area of Tamanmartani Village, Kalasan, Sleman, DIY. Meanwhile, parenting patterns that are less responsive and supportive in breastfeeding and breastfeeding are suspected to be factors that trigger nutritional health problems of children under five. It is due to the ignorance of parents and caregivers in providing exclusive breastfeeding and complementary feeding according to WHO standards. This situation is very high-risk accounts for the number of stunting cases in Indonesia. Especially in Sleman Regency, so that the Community Partnership Program Proposal Team conducts community empowerment activities. It is the form of training in the context of stunting prevention. The targets of this activity are pregnant women, mothers who have toddlers, and health cadres. The method of activities used includes the provision of health education, simulations, and training or practice through the MP ASI cooking competition and process evaluation. Increased knowledge and target skills in exclusive breastfeeding and MP ASI standard WHO is the output of this empowerment activity. Besides, the dissemination of events in the form of scientific publication products and training modules. In general, this empowerment activity can increase target knowledge and skills. The evaluation of the process shows the enthusiasm of the target in implementing the knowledge that the Proponent Team provided through health education and simulations. It hoped that this activity could be continue in other hamlets located in the Tamanmartani village area. It can contribute to preventing and reducing the number of stunting cases in Indonesia.
\end{abstract}

\begin{tabular}{lcll} 
Keywords: & $\begin{array}{l}\text { Complementary Foods, Eksklusive Breastfeeding, Kalasan, Randugunting, } \\
\text { Stunting. }\end{array}$ & & \\
\hline Received: & Revised: & Accepted: & Available online: \\
08.10 .2019 & 11.01 .2020 & 27.01 .2020 & 14.02 .2020 \\
\hline
\end{tabular}

\section{Suggested citation:}

Isni, K., \& Dinni, S. M. (2020). Pencegahan stunting melalui pelatihan pemberian ASI eksklusif dan Makanan Pendamping ASI (MP ASI). Jurnal Pengabdian Pada Masyarakat, 5(1), 133-140. https://doi.org/10.30653/002.202051.266

Open Access I URL: http://ppm.ejournal.id/index.php/pengabdian/article/view/266

${ }^{1}$ Corresponding Author: Fakultas Kesehatan Masyarakat, Universitas Ahmad Dahlan. Jl. Prof. Dr. Soepomo, SH, Warungboto, Umbulharjo, Yogyakarta 55164, Indonesia. Email: khoiriyah.isni@ikm.uad.ac.id 


\section{PENDAHULUAN}

Kejadian balita pendek atau sering disebut dengan stunting adalah salah satu masalah gizi yang dialami oleh balita di dunia saat ini. Pada tahun 2017 terdapat 22,2\% atau sekitar 150,8 juta balita di dunia mengalami stunting. Namun angka ini sudah mengalami penurunan jika dibandingkan dengan angka stunting pada tahun 2000 yaitu $32,6 \%$. Menurut World Health Organization (WHO), Indonesia termasuk ke dalam negara ketiga dengan prevalensi tertinggi di regional Asia Tenggara/South-East Asia Regional (SEAR). Rata-rata prevalensi balita stunting di Indonesia tahun 2005-2017 adalah 36,4\%. Berdasarkan data Pemantauan Status Gizi (PSG) selama tiga tahun terakhir, pendek memiliki prevalensi tertinggi dibandingkan dengan masalah gizi lainnya seperti gizi kurang, kurus, dan gemuk. Prevalensi balita pendek mengalami peningkatan dari tahun 2016 yaitu 27,5\% menjadi 29,6\% pada tahun 2017 (Kemenkes RI, 2018).

Periode emas dalam dua tahun pertama kehidupan anak dapat tercapai optimal apabila ditunjang dengan asupan nutrisi tepat sejak lahir. Air Susu Ibu (ASI) sebagai satu-satunya nutrisi bayi sampai usia enam bulan dianggap sangat berperan penting untuk tumbuh kembang, sehingga rekomendasi dari pemerintah, bahkan kebijakan WHO mengenai hal ini telah ditetapkan dan dipublikasikan ke seluruh dunia. Status gizi balita merupakan hal yang penting harus diketahui oleh setiap orang tua. Perlunya perhatian lebih dalam tumbuh kembang di usia balita didasarkan fakta bahwa kurang gizi yang terjadi pada masa emas ini, bersifat tidak dapat pulih. Sebagian besar kejadian kurang gizi dapat dihindari apabila mempunyai cukup pengetahuan tentang cara pemeliharaan gizi dan mengatur makanan anak. Ketidaktahuan tentang cara pemberian makanan bayi dan anak, dan adanya kebiasaan yang merugikan kesehatan, secara langsung dan tidak langsung menjadi penyebab utama terjadinya masalah kurang gizi dan infeksi pada anak, khususnya pada umur dibawah 2 tahun. Kenyataannya, praktek pemberian MP-ASI dini sebelum usia enam bulan masih banyak dilakukan di negara berkembang seperti Indonesia. Hal ini akan berdampak terhadap kejadian infeksi yang tinggi seperti diare, infeksi saluran napas, alergi hingga gangguan pertumbuhan.

Asupan nutrisi yang tidak tepat juga akan menyebabkan anak mengalami malnutrisi yang akhirnya meningkatkan angka kejadian morbiditas dan mortalitas. Kurang gizi pada balita dapat berdampak terhadap pertumbuhan fisik maupun mentalnya. Anak kelihatan pendek dan kurus dibandingkan teman-teman sebayanya yang lebih sehat, ketika memasuki usia sekolah tidak bisa berprestasi menonjol karena kecerdasannya terganggu. Gizi memegang peranan penting dalam siklus hidup manusia. Kekurangan gizi pada ibu hamil dapat menyebabkan Berat Badan Lahir Rendah (BBLR) dan dapat pula menyebabkan penurunan tingkat kecerdasan. Pada bayi dan anak, kurang gizi dapat menimbulkan gangguan pertumbuhan dan perkembangan bayi dan anak yang apabila tidak diatasi secara dini akan berlanjut hingga dewasa. Usia 0-24 bulan merupakan masa pertumbuhan dan perkembangan yang pesat, sehingga dapat diistilahkan sebagai periode emas sekaligus kritis. Periode emas dapat diwujudkan apabila pada masa bayi dan anak memperoleh asupan gizi yang sesuai dengan tumbuh kembang yang optimal. Sebaliknya pada bayi dan anak pada masa usia 0-24 bulan tidak memperoleh makanan sesuai dengan kebutuhan gizi, maka periode emas ini akan berubah menjadi periode kritis yang akan mengganggu tumbuh kembang bayi dan anak, saat ini maupun selanjutnya (Mufida, Widyaningsih, \& Maligan, 2015). 
Kekurangan gizi pada bayi akan menyebabkan gangguan pertumbuhan dan perkembangan, apabila tidak diatasi secara dini akan berdampak hingga dewasa. Pada usia 0 - 24 bulan seorang bayi adalah masa pertumbuhan dan perkembangan yang pesat, atau disebut juga sebagai periode emas sekaligus periode kritis. Periode emas dapat terwujudkan apabila pada masa ini bayi dan anak memperoleh asupan gizi yang sesuai untuk tumbuh kembang optimal. Faktor eksternal seperti pola asuh orang tua, asupan gizi (pemberian, frekuensi dan durasi pemberian ASI serta pemberian MP-ASI), stimulasi dan sosial ekonomi dapat berpengaruh terhadap pertumbuhan bayi (Al Rahmad, 2017).

Salah satu masalah kekurangan gizi yang mengintai bayi dan balita adalah stunting. Stunting menandakan terjadinya gangguan pertumbuhan yang potensial pada tinggi badan dimana penyebabnya meliputi retardasi pertumbuhan di dalam intrauterine, gizi yang tidak terpenuhi untuk menunjang pertumbuhan dan perkembangan serta penyakit infeksi selama awal kehidupan yang akan mempengaruhi kehidupan mereka selanjutnya (Probosiwi, Huriyati, \& Ismail, 2017). Sementara itu, kasus stunting di Indonesia masih tinggi diberbagai daerah, termasuk Kabupaten Sleman, DIY.

Kabupaten Sleman merupakan Kabupaten dengan jumah penduduk terbanyak diantara kabupaten/kota lainnya di Provinsi Daerah Istimewa Yogyakarta. Sementara itu, Kecamatan kalasan menjadi salah satu kecamatan di wilayah Kabupaten Sleman yang memiliki jumlah bayi terbanyak, sehingga menjadi daerah rawan stunting. Tahun 2016, Kecamatan Kalasan diketahui sebagai daerah dengan angka prevalensi stunting tertinggi di Kabupaten Sleman yaitu 19,82\% (Pemkab Sleman, 2017). Kemudian tahun 2017, Kecamatan Kalasan masih termasuk lima besar kecamatan dengan jumlah kasus stunting balita tertinggi di Kabupaten Sleman, selain Kecamatan Minggir, Seyegan, Moyudan, dan Prambanan (Pemkab Sleman, 2019).

Berdasarkan hasil survei pendahuluan yang telah dilakukan terkait tingginya angka kejadian stunting di Wilayah Kecamatan Kalasan, khususnya Desa Tamanmartani, ditemukan beberapa kajian masalah. Adapun kajian masalah tersebut diantaranya masih rendahnya kesadaran akan pemberian ASI Eksklusif dan pemberian makanan pendamping ASI (MP ASI) yang belum sesuai standar World Health Organization (WHO). Hal ini disebabkan karena ibu yang memiliki balita adalah ibu pekerja, sehingga balita diasuh oleh keluarga atau saudara. Oleh karena itu, perlu dilakukan pelatihan mengenai manajemen pemberian ASI eksklusif dan pemberian Makanan Pendamping ASI (MP ASI) sesuai standar WHO, tidak hanya kepada para ibu yang memiliki balita, namun juga kepada pengasuh dan kader kesehatan masyarakat di lingkungan Dusun Randugunting, Desa Tamanmartani, Kalasan, Sleman.

Hal ini sejalan dengan kegiatan pengabdian masyarakat dilaksanakan di Posyandu Bunga Tanjung menggunakan metode oral atau presentasi kepada masyarakat. Sebanyak 20 responden (100\%), diperoleh $90 \%$ responden yang memiliki pengetahuan dengan kategori baik. Sosialisasi tentang ASI Eksklusif merupakan wujud dalam pemberian informasi kepada setiap ibu yang memiliki bayi maupun calon ibu (Mursyida, Ayuningtiyas, \& Hasan, 2018). Pengabdian masyarakat yang lain yaitu dilakukan oleh Nur Laila tahun 2019 dengan hasilnya yaitu bahwa keberadaan kader PARAPAM dapat memberikan pendidikan kesehatan dan dukungan kepada masyarakat dalam menyusui dan pemberian makanan pendamping ASI. Informasi dan 
dukungan kader PARAPAM mampu meningkatkan pemberian ASI Eksklusif dan MPASI pada Bayi (Laila \& Riyanti, 2019).

\section{METODE}

Kegiatan pengabdian masyarakat dilaksanakan oleh Tim Pelaksana Program Kemitraan Masyarakat (PKM) Kemenristekdikti tahun 2019. Kegiatan ini dilakukan oleh dua orang Dosen Universitas Ahmad Dahlan dari Fakultas Kesehatan Masyarakat dan Fakultas Psikologi. Sasaran dari program ini adalah ibu yang mempunyai balita, bagi ibu hamil serta ibu-ibu kader kesehatan di Dusun Randugunting, Desa Tamanmartani, Kalasan, Sleman, DIY.

Fokus materi kegiatan pengabdian masyarakat mengenai manajemen pemberian ASI Eksklusif dan pemberian MP ASI standar WHO yang tepat sesuai umur.

Metode yang digunakan dalam pelaksaanan kegiatan pengabdian masyarakat ini adalah sebagai berikut :

1) Pendidikan masyarakat atau penyuluhan sebagai upaya mengawali proses pemberdayaan dan pelatihan. Tahap ini bertujuan untuk menghasilkan perubahan sudut pandang peserta tentang manajemen pemberian ASI Eksklusif dan MP ASI standar WHO yang tepat sesuai umur anak. Materi penyuluhan meliputi pentingnya ASI, persiapan menyusui sebelum persalinan, Hypnoeating, menu MP ASI 4 Bintang dan awal MP ASI menu tunggal.

2) Simulasi, bertujuan untuk mensinergikan antara pengetahuan sasaran mengenai pembuatan MP ASI standar WHO yang diperoleh melalui proses pendidikan masyarakat atau penyuluhan.

3) Pelatihan atau praktik, sebagai upaya lanjutan dalam proses pemberdayaan yang bertujuan untuk meningkatkan keterampilan peserta agar dapat membuat MP ASI untuk balita dengan menu 4 bintang.

Kegiatan ini bekerjasama dengan Sanggar ASI Indonesia, sebagai salah satu Social Enterprise yang focus dibidang ASI dan MP ASI. Pelaksanaan kegiatan selama dua hari, yaitu pertama, hari Minggu tanggal 28 Juli 2019 dengan rincian kegiatan yaitu pemberian pendidikan masyarakat atau penyuluhan mengenai manajemen pemberian ASI Eksklusif dan MP ASI standar WHO. Kemudian dilanjutkan dengan kegiatan simulasi atau demo memasak MP ASI standar WHO sesuai tekstur dan umur anak. Kedua, kegiatan pelatihan atau praktik dilakukan pada hari Minggu tanggal 4 Agustus 2019. Seluruh rangkaian kegiatan pengabdian ini bertempat di Kediaman Dukuh Randugunting, Desa Tamanmartani, Kalasan, Sleman, DIY.

\section{HASIL DAN PEMBAHASAN}

\section{Pendidikan Kesehatan atau Penyuluhan}

Kegiatan pengabdian masyarakat ini diawali dengan sesi pertama yaitu pemberian materi tentang ASI yang disampaikan oleh pemateri dari Sanggar ASI. Pemberian materi ini diberikan agar peserta dapat menambah pengetahuan mengenai mengapa 
harus ASI, persiapan menyusui sebelum persalinan. Sesi selanjutnya yaitu penyampaian materi terkait pengetahuan tentang Menu MP ASI dengan 4 bintang meliputi bahan-bahan makanan yang tepat yang digunakan dalam bahan pembuatan MP ASI, tekstur serta kesesuaian umur anak, adapun materi tentang hypnoeating yaitu meliputi bagaimana ibu mendidik anak dalam kebiasaan makan dengan teladan dan sikap positif.

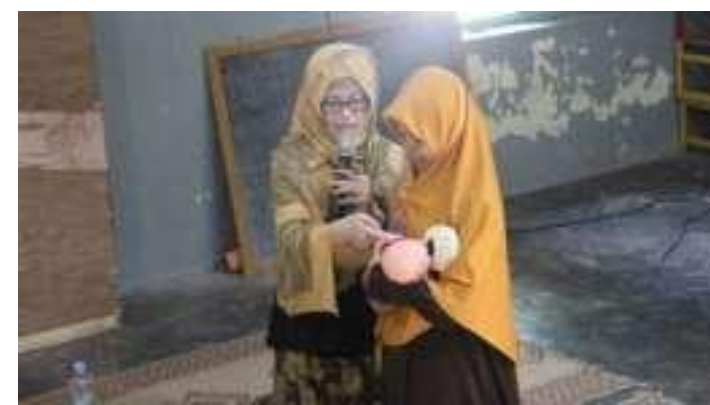

Gambar 1. Pelatihan pemenuhan gizi seimbang bayi mengenai Edukasi Pentingnya Menyusui dengan posisi dan pelekatan yang benar

\section{Simulasi}

Metode selanjutnya adalah simulasi yang bertujuan untuk mensinergikan antara pengetahuan sasaran mengenai pembuatan MP ASI sesuai standar WHO yang diperoleh melalui proses pendidikan masyarakat atau penyuluhan. Sehingga hasil yang diperoleh lebih maksimal dengan adanya simulasi. Simulasi yang dilakukan meliputi simulasi pembuatan MP ASI untuk anak usia 6-9 bulan, 9-12 bulan, dan diatas 12 bulan.

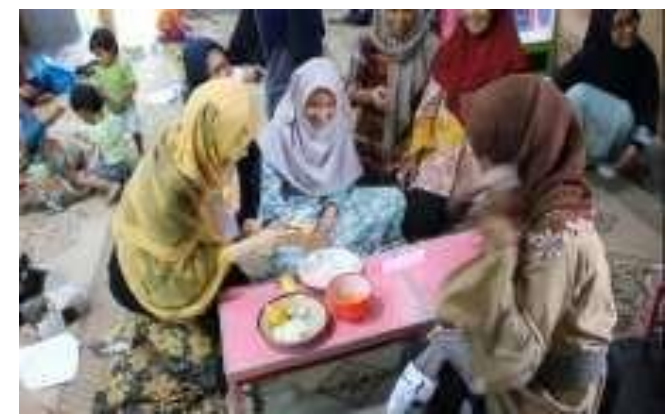

Gambar 2. Simulasi Pembuatan MP ASI sesuai gizi seimbang dan panduan WHO

\section{Pelatihan atau Praktik}

Tahap akhir dari proses pemberdayaan yaitu pemberian pelatihan. Tujuannya adalah untuk meningkatkan keterampilan sasaran dalam pembuatan MP ASI sesuai standar WHO yang meliputi menu 4 bintang sesuai tekstur dan umur anak. Bentuk kegiatan pelatihan ini berupa lomba masak menu MP ASI. Sasaran dibagi menjadi 5 kelompok. Menu MP ASI yang dimasak sesuai dengan hasil undian yang diambil oleh ketua kelompok. Kemudia setiap kelompok bertugas memasak, menghidangkan, dan mempresentasikan hasil olahan MP ASI. 

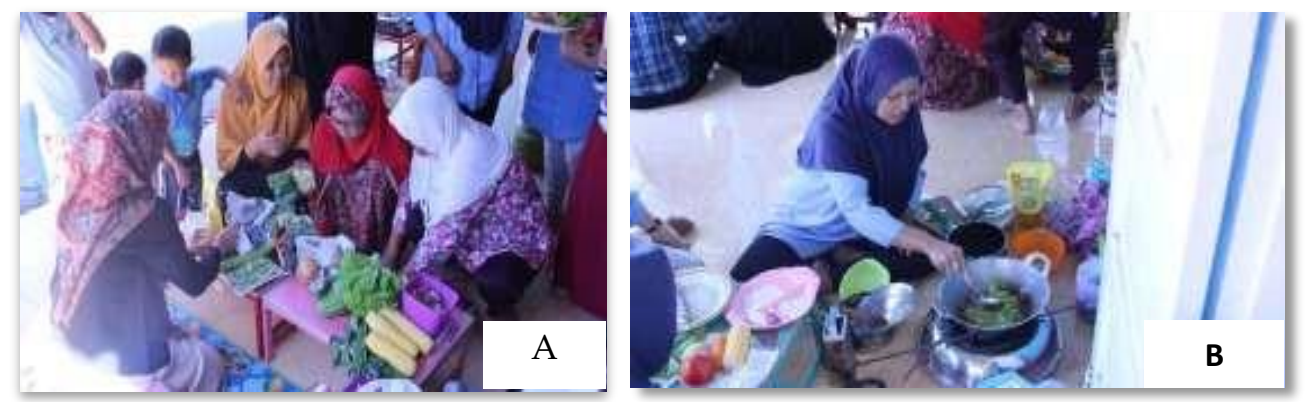

Gambar 3. Pelatihan atau praktik pembuatan MP ASI dalam lomba masak (A) Pemilihan Bahan Masakan MP ASI 4 bintang; (B) Proses Pengolahan Masakan MP ASI 4 Bintang

\section{Evaluasi Proses}

Evaluasi kegiatan dilakukan melalui penilaian hasil pelatihan atau praktik pembuatan MP ASI standar WHO sesuai tekstur dan umur anak. Penilaian berfokus pada proses, bukan hasil dari kegiatan pengabdian. Penilaian dilakukan oleh Tim Juri, yaitu Tim Pengusul PKM dan perwakilan dari pemerintah Desa setempat, yaitu sekretaris Desa. Penilaian menggunakan lembar penilaian yang berisi delapan indicator. Adapun indicator tersebut adalah kelengkapan bahan sumber 4 bintang, tekstur makanan, kombinasi bahan makanan, penyajian makanan, higienitas, cita rasa, kreativitas resep, dan penampilan mempresentasikan hasil olahan MP ASI.

Hasil penilaian ketiga juri digunakan sebagai penentuan juara kelompok, sebagai berikut : juara I adalah kelompok 5 dengan total skor 72,3; Juara II adalah kelompok 2 dengan total skor 70,9; Juara III adalah kelompok 4 dengan total skor 66,4; Juara harapan I adalah kelompok 3 dengan total skor 63,7.

Para Juara diberikan hadiah sebagai bentuk apresiasi lomba memasak MP ASI. Pemberian hadiah ini berupa peralatan MP ASI yang sekaligus sebagai hibah sarana dan prasarana.

Kegiatan pemberdayaan masyarakat ini diikuti oleh ibu yang memiliki balita, ibu hamil, dan kader kesehatan di Dusun Randugunting, Desa Tamanmartani, Kalasan, Sleman, DIY. Dusun ini merupakan dusun yang memiliki jumlah balita terbanyak di wilayah Desa Tamanmartani, yang mana apabila tidak diberikan intervensi, sangat berpotensi dalam menyumbang angka stunting di wilayah Kecamatan Kalasan, Sleman, DIY.

Kegiatan pemberdayaan dibuka dengan perkenalan dari Tim pengusul dan Narasumber yang berasal dari Sanggar ASI Indonesia. Secara umum, focus kegiatan dibagi menjadi tiga bagian yaitu transfer pengetahuan melalui pendidikan kesehatan atau penyuluhan, simulasi, dan dilanjutkan dengan pelatihan atau praktik. Ketiga formulasi metode ini diharapkan dapat menunjang peningkatan pengetahuan dan keterampilan sasaran dalam mencegah kejadian stunting melalui manajemen pemberian ASI Eksklusif dan MP ASI standar WHO sesuai tektur dan umur anak.

Secara umum, kegiatan pemberdayaan ini dapat dikatakan berhasil. Hal ini ditunjukkan dengan kreativitas sasaran dalam mengolah, menyajikan, dan mempresentasikan menu MP ASI standar WHO sesuai tekstur dan umur anak. 
Pengabdian masyarakat yang sejenis dilakukan oleh Sukmawati didapatkan hasil bahwa perubahan yang signifikan dari pengetahuan dan skill keluarga dan kader kesehatan sebelum dan sesudah pelatihan. Setelah kegiatan pelatihan ini diharapkan keluarga dan kader kesehatan dapat berperan aktif untuk menyampaikan informasi kepada ibu hamil tentang manfaat ASI Aksklusif (Sukmawati, dkk, 2019). Penelitian yang sejenis telah dilakukan oleh Dwitama didapatkan hasilnya bahwa terdapat hubungan antara pemberian ASI eksklusif dan MP-ASI dengan balita pendek masingmasing $\mathrm{p}<0,05$ dan $\mathrm{p}>0,05$. Terdapat hubungan antara pemberian ASI eksklusif dan balita pendek, tetapi tidak terdapat hubungan antara MP-ASI dan balita pendek (Dwitama, 2018).

Menurut penelitian yang dilakukan oleh Mulyani didapatkan hasil bahwa kegiatan yang dilakukan dengan melibatkan bidan dan kader serta dengan menggunakan teknik diskusi dan ceramah memberikan efek perubahan pengetahuan yang signifikan yaitu dimana diawal ibu balita memiliki pengetahuan $30.0 \%$ baik tentang pemberian MPASI, meningkat menjadi 58.9\% memiliki kategori pengetahuan baik tentang MPASI. Oleh karenanya, perlu diintensifkan kegiatan diskusi dan ceramah tentang kesehatan dan gizi dengan memberdayakan bidan dan kader sebagai agent of change (Mulyani, 2017). Selain itu, pengabdian masyarakat yang dilakukan oleh Umilasari didapatkan hasil bahwa pelatihan menunjukkan para ibu yang memiliki bayi mulai memahami bagaimana pentingnnya memberikan MP-ASI dengan memperhatikan unsur AFATVAH (Age, Frequency, Amount, Texture, Variety, Active Responsive, Hygine). Sasaran senang karena ada tambahan edukasi mengenai MP-ASI yang kaya energi, protein, mikronutrien, mudah dimakan anak, disukai anak, berasal dari bahan makanan lokal dan terjangkau, serta mudah disiapkan (Umilasari, 2018).

Harapannya kegiatan pemberdayaan mengenai pelatihan manajemen pemberian ASI Eksklusif ini dan MP ASI standar WHO sesuai tektstur dan umur bayi dapat berkontribusi dalam mencegah dan menurunkan angka kasus stunting di Indonesia.

\section{SIMPULAN}

Berdasarkan rangkaian kegiatan yang telah dilakukan oleh Tim Pengusul, dapat disimpulkan bahwa kegiatan pemberdayaan mengenai manajemen pemberian ASI Eksklusif dan pembuatan MP ASI standar WHO menunjukkan hasil sesuai dengan tujuan kegiatan. Metode pelaksanaan kegiatan pemberdayaan dilakukan melalui pendidikan kesehatan, simulasi, dan pelatihan atau praktik. Harapannya dengan meningkatnya pengetahuan dan keterampilan sasaran, dapat diimplementasikan dalam pengasuhan balita, sehingga dapat berpartisipasi dalam mencegah kejadian stunting di Indonesia.

\section{Ucapan Terimakasih}

Ucapan terima kasih kami ucapkan kepada DRPM Kemenristekdikti sebagai pemberi hibah dana kegiatan pengabdian masyarakat pada skema Program Kemitraan Masyarakat (PKM) serta Lembaga Penelitian dan Pengabdian Masyarakat (LPPM) Universitas Ahmad Dahlan yang telah memberikan dukungan penuh dan Pemerintah 
Desa Tamanmartani, khususnya Dusun Randugunting, Kecamatan Kalasan, Sleman, DIY atas berbagai fasilitas dan dukungan yang telah disediakan demi kelancaran kegiatan pengabdian masyarakat ini.

\section{REFERENSI}

Al Rahmad, A. H. (2017). Pemberian ASI dan MP-ASI terhadap Pertumbuhan Bayi Usia 6-24 Bulan. Jurnal Kedokteran Syiah Kuala, 17(1), 8-14.

Kemenkes RI. (2018). Situasi balita pendek (Stunting) di Indonesia. Jakarta: Pusdatin Kementerian Kesehatan RI.

Laila, N., \& Riyanti, E. (2019). Peningkatan pemberian ASI dan MP-ASI melalui kader Parapam di Desa Karanganyar, Karanganyar Kebumen. ABDIMAS: Jurnal Pengabdian Masyarakat, 2(1), 131-139.

Mufida, L., Widyaningsih, T. D., \& Maligan, J. M. (2015). Prinsip dasar makanan pendamping air susu ibu (MP-ASI) untuk bayi 6-24 bulan. Jurnal Pangan dan Agroindustri, 3(4), 1646-1651.

Mursyida, E., Ayuningtiyas, R., \& Hasan, N. (2018). Pentingnya pemberian ASI eksklusif pada bayi di Posyandu bunga Tanjung Desa Tanah Merah. Jurnal Pengabdian Masyarakat Multidisiplin, 2(3), 210-215.

Pemkab Sleman. (2017). Rekapitulasi Hasil pemantauan status gizi (PSG). Sleman: Pemerintah Kabupaten Sleman.

Pemkab Sleman. (2019). Letak geografis dan letak wilayah kabupaten Sleman. Retrieved June 20, 2019 from http://www.slemankab.go.id/profil-kabupatensleman/geografi/letak-dan-luas-wilayah

Probosiwi, H., Huriyati, E., \& Ismail, D. (2017). Stunting dan perkembangan pada anak usia 12-60 bulan di Kalasan. Berita Kedokteran Masyarakat, 33(11), 559-564.

\section{Copyright and License}

This is an open access article distributed under the terms of the Creative Commons Attribution 4.0 International License, which permits unrestricted use, distribution, and reproduction in any medium, provided the original work is properly cited. (c) 2020 Khoiriyah Isni, Siti Muthia Dinni. 